\title{
Bukott tanárok történetei
}

\author{
Petres Csizmadia Gabriella \\ Nyitrai Konstantin Filozófus Egyetem Közép-európai Tanulmányok Kara \\ Magyar Nyelv- és Irodalomtudományi Intézet
}

\begin{abstract}
Absztrakt
Tanulmányomban Komlós Aladár Néró és a VII. A c. regényének identitáskonstrukcióit vizsgálom, elsősorban egy-egy tanár karakterábrázolására fókuszálva, majd az értelmezés eredményeinek tanórai keretek közti alkalmazására vázolok fel lehetőséget. Az 1935-ben megjelent iskolaregény egyrészt a tanár-diák kapcsolat szövevényességét mutatja be, másrészt érzékletesen ábrázolja a tanárszereplők személyes és szakmai identitásának képlékenységét. A karrierregényként is felfogható történetben nyomon kísérjük a főszereplő népszerűségvesztésének az eseményeit, amelyek mind a kollégák, mind a tanítványok körében visszafordíthatatlan folyamatként uralják a mindennapjait. Az elemzést kísérő módszertani útmutató során kooperatív oktatási módszerek segítségével kínálok alternatívát a regény napjaink irodalomoktatásában történő elhelyezésére.
\end{abstract}

Kulcsszavak: iskolaregény, identitáskonstrukció, tanári identitás, személyes identitás, irodalom-módszertan

„Az a tanár, aki túl sokodaadással él az iskolának, eleve gyanús..." (Komlós, 1958, p. 94)

A 20. század magyar irodalmában több olyan regényt találunk, amely a tanárdiák kapcsolat problematikusságát ábrázolja - gondoljunk csak a legismertebbekre, Kosztolányi Dezső Aranysárkányára (Kosztolányi, 1925), Szabó Magda Abigéljére (Szabó, 1970) vagy Móricz Zsigmond Légy jó mindhalálig (Móricz, 1920) című művére. Az iskolai miliő választása azonban nem jelenti feltétlenül azt, hogy ifjúsági regényt olvasunk, hiszen a célcsoport kijelölésével megnevezett szövegtípus nem merül ki pusztán a gyermeki(nek képzelt) téma és kontextus felvetésében (Baranyai, 2003). Előfordulhat, hogy a téma alapján gyermek- és ifjúsági irodalomba tartozó szöveg nem találkozik a befogadók olvasói igényeivel, vagy a gyermekinek tűnő tematika túlmutat a korosztály befogadó-képességének határain (Kiss, 2000, p. 18), esetleg az adott témát csupán a gyermekszereplők és gyermeki kontextus minősíti gyermekirodalminak. 
Komlós Aladár Néró és a VII. A című regénye esetében ez utóbbi lehetőséggel találkozunk, mivel az iskolás közeg csupán díszletként szerepel, mellékessé válik a történetben, és Perényi Zoltán tanáridentitása a háttérbe szorul, hiszen pedagógusi munkájáról csupán marginális adatokat szerzünk. A főhőst nem szakmai tudásának hiányosságai, pedagógiai-módszertani eljárásai, hanem a tanári és magánemberi identitásának egymásba csúsztatása, illetve felcserélése teszi nevetségessé. Elsősorban férfiként vall kudarcot - tanárként való elbukása már csak ennek a természetes folyamodványa. A szöveg ezáltal túlmutat a tanár-diák kapcsolat bemutatásán, és a tanár helyett a férfire, pontosabban az idősödő férfi fiatalabb nőkhöz való viszonyára irányítja a figyelmet. A kulcsregényként (Ujvári, 1936), lélektani regényként (Karinthy, 1936) interpretált művet ezért nem csupán a bukott tanár, hanem a bukott férfi karikatúrájaként értelmezem.

A regény helyszíne egy budapesti lánygimnázium. Az intézmény hétköznapjaiban csupán az jelent színfoltot, ha egy-egy új tanár érkezik a katedrára. A lányiskola belső életét ezáltal egy ciklikusan ismétlődő folyamat határozza meg: a diákok érdeklődésének középpontjába mindig a legfiatalabb tanár kerül, aki - akaratán kívül, a lányok szeszélyének kiszolgáltatva - kiszorítja elődjét kiváltságos(nak vélt) helyzetéből. Perényi is belesodródik ebbe a szituációba, hiszen háromféle szerepkörben mutatkozik: érkezésével átveszi elődjétől a kedvenc tanár pozícióját, egy ideig élvezi a diákok érdeklődését és szeretetét, majd kegyvesztettként tovább kell adnia kiemelt státuszát egy fiatalabb kollégájának. Bukásának gyökere abban található, hogy szerepeit nem önként vállalja fel, hanem tanítványai helyezik önkényesen egyik szerepkörből a másikba. Ez nem csupán azt jelenti, hogy elveszíti uralmát saját élete felett, hanem az általa feltételezett alá-fölérendelt kapcsolat is megfordul közte és diákjai között. Perényi nem is sejti, hogy a diáklányok hatalmából kifolyólag hódító helyett behódolóvá, uralkodó helyett irányított szubjektummá, zsarnok helyett kizsákmányolttá válik.

A történet jelenében a főhős harmadik identitásával ismerkedünk meg, ahol Perényit már mint Nérót emlegetik: a lányok azonban még a kegyetlenkedés hatalmától is megfosztják, hiszen csak a tanóra ideje alatt, tanári identitásának 45 percére emelkedhet föléjük, tanórán túl csak megvetéssel és lenézéssel gondolnak rá. Esetlensége abban látható, hogy Néróval való azonosítása valójában nem az erővel és hatalommal bíró császári identitás megidézését jelenti, hanem a megtört és szánalmas, idejétmúlt, gyenge férfiét. A Klausek által Nérókomplexumnak (Komlós, 1958) nevezett identitása tehát magában hordozza a bukást, hiszen tanári zsarnokoskodása a férfi szeretetéhségét hivatott eltakarni - azonban eltakarás helyett inkább leleplező hatást, sértett hiúságának kiszolgáltatását eredményezi.

A szemben álló felek ereje nemi identitásukból fakad: a szende szűznek, angyali tisztaságúnak képzelt lányok valójában a femme fatale szerepkörét öltik magukra, és szirénként büvölik a kezük közé kaparintott férfiakat. Erotikus harc ez a javából, ahol a tanár-diák közti szeretetet szerelem váltja fel. 
A kamaszlányok erotikum iránti vágyakozása olyannyira áthatja az iskola légkörét, hogy nemcsak a férfitanárok, hanem tanárnők iránt is szerelemre lobbannak (Komlós, 1958). Perényi úgy véli, magánemberi identitását áldozza fel tanársága érdekében, holott fordítva történik, hiszen tanári munkáját is az osztályokból áradó fojtott szexualitás motiválja. Tanítás helyett az erotikus légkör megteremtését és lebegtetését helyezi előtérbe, és mindent ennek rendel alá - a feleltetés, magyarázat, ügyelet tevékenységét flörtölésre használja fel, és élvezetet jelent számára az előadások során használt ismeretlen kifejezések alkalmazása, melyekkel mintegy beavatja a lányokat a felnőttek világába. A diákok olyan ügyesen irányítják a köztük lévő viszonyt, hogy Perényi úgy gondolja, „csak rajta állna, s bármelyik növendéke azonnal boldogan lenne az övé” (Komlós, 1958, p. 31) Az „édes kábulat” (Komlós, 1958. 32. o.), „a burkolt erotikus érintkezés varázsa" (Komlós, 1958, p. 35) annyira megszédíti őt, hogy nem veszi észre, amikor a "füszeres és izgató” (Komlós, 1958, p. 36) lányok szellemileg kasztrált férfit - és ezáltal tanárt - csinálnak belőle.

A diákok körében akkor szünik meg végleg imádott tanárként funkcionálni, amikor a szöveg végén az utolsó rajongója, Erdős Aliz is kiábrándul belőle - éppen amiatt, hogy Perényi elkezd újra magánéletet élni. A nyíltan felvállalt plátói szerelmével szemben ugyanis valódi testi kapcsolatát eltitkolja, ezáltal nemcsak a tanítványai, de szeretője szemében is elbukik, hiszen képtelen elfogadni, hogy a fiatalok vélt rajongása csak illúzió a valóság hétköznapiságával és szürkeségével szemben. Hús-vér szerelmi kapcsolatát alárendeli a plátói szerelem érdekében, hiszen álomvilágában önmagát is idealizáltan látja kopaszodó-kövéredő testalkata és naiv-önhitt természete helyett. Perényi tragikomikumát tehát az öregedő férfi fiatal lányok utáni vágyakozása generálja, hiszen a tanár-diák kapcsolatot nemcsak a nemi, hanem az életkori különbség is bonyolítja. Az iskolát áthatják a „szerelmi és hiúsági harcok, gyermeklányok és öregedő emberek küzdelmei egymásért és egymás ellen" (Komlós, 1958, p. 72). Perényi úgy próbálja áthidalni a diáklányok és közte tátongó életkori szakadékot, hogy külsejére nevetségesen nagy gondot fordítva, kirívóan-kihívóan viselkedik tanítványai körében, méltóságteljes tanár helyett ripacs kéjenccé válva. Népszerüségének csökkenését életkorának elörehaladásával hozza összefüggésbe - valójában tehát nem a lányokba, még csak nem is az „iskola idealizált világába” (Karinthy, 1936), hanem önmaga és környezete által idealizált fiatalkori énjébe szerelmes, és a tanítványokért folyó harcával saját fiatalságát próbálja visszaszerezni. Perényi nárcisztikus harcot vív, a megunt és kiöregedett sztár értékvesztésének kétségbeesett csatáját. Ezzel tanári szerepkörét nem csupán alárendeli, hanem fel is számolja, mivel a tanórákon is csupán hódító férfiként kíván tetszelegni.

Azonban nem csupán Perényi az egyetlen szereplő, aki az idősödő szerelmes férfi szerepkörében mutatkozik - Glas tanár úr Erdős Aliz iránti epekedése ugyanolyan nevetséges, mint Perényi rajongása. Kettejük tragédiája abban különbözik, hogy Glas tudatában van öregedésének, megelégedik egyetlen lány plátói imádásával, és rajongása nélkülöz minden erotikát. Ennek érdekében 
felvállalja önmaga megalázását, nevetségessé tételét is. Perényi azonban egy egész osztályt üldöz a szerelmével, Glasszal szemben nem hajlandó elfogadni szerelmének viszonzatlanságát, és szélmalomharcba kezd a diákok figyelméért. Glas rajongása elkerüli a nyilvánosságot, mivel nem kívánja megvédeni a sértett hiúságát, eszközeiket tekintve viszont sokban megegyeznek a hódítási kísérleteik. Egy furcsa hármas alakul ki a történetben: míg Glas tisztes távolból követi Erdőst, és a lány megnyerése érdekében feltárja a naplóját is, Erdős Aliz a saját naplóját olvasgatja, amiben Perényiről jegyez fel apróságokat, és Perényit követi, neki ír titkos leveleket. A lány rajongása Perényi leleplezésével abbamarad, Glast azonban semmilyen észérv nem tudja eltántorítani tanítványa imádatától. Az idős férfi rajongása tehát lényegesen irreálisabb és kitartóbb a fiatal diáklány idősebb tanár utáni vágyánál, Perényi és Glas epekedése ezáltal az idősödő férfitanárok karikatúrájaként funkcionál.

Perényi és Glas története nem egyedülálló: ugyanez a sors vár a legfiatalabb kollégára, Faragó Aurélra is, aki egyelőre Perényi bukásának előidézőjeként szerepel, azonban a szöveg több helyen utal Faragó státuszvesztésének előjeleire. Az elbukott, megalkuvó férfi sorsát foglalja magába Knöpfler igazgató úr és Klausek szerkesztő története is. Knöpfler feltörekvő, spekulatív, helyezkedő, zsarnokoskodásra hajló, ugyanakkor félművelt és kicsinyes férfiként jelenik meg, aki a vezetői pozíciójának megőrzése érdekében feláldozza kollégája becsületét, bukása tehát erkölcsi természetü; Klausek pedig a művészek sztereotípiáját ölti magára, és az éjszakai életbe belevetve magát, a szerkesztők elképzelt életmódjához és magatartásához alkalmazkodva fanyar-gúnyos hangnemet enged meg magának.

Valójában tehát valamennyi férfi egy elképzelt karaktert imitál, és hétköznapjaik azzal telnek, hogy kétségbeesetten igyekeznek felvállalt szerepköreiknek megfelelni. Perényi azonban kicsúszik saját szerepéből, és természetes énjétől megfosztva identitászavarba kerül. Karaktere mégis eltér a többitől, mivel ő az egyetlen a többi tanár között, aki végül kezébe veszi a tükrét, megvizsgálja az arcát, és bevallja önmagának póza nevetségességét.

\section{A Néró és a VII. A módszertani feldolgozása}

A regényt 15-16 éves középiskolás diákok házi olvasmányaként ajánlom. A módszertani javaslatok a kooperatív oktatás eljárásait alkalmazzák, és elsősorban a kreatív írás, illetve drámapedagógia gyakorlataiból merítenek (vö. Kaposi, 2002; Samu, 2004; Pethőné, 2005). A szöveg feldolgozása a csoport befogadóképességétől függően egy vagy két tanórát vesz igénybe.

1. Árulkodó cím (kiscsoportos munka, jóslás, grafikus ábrázolás, frontális megbeszélés): A cím értelmezését már a szöveg megismerése előtt megkezdjük. A müvet bevezető órán a tanár jóslásra invitálja a diákokat - kiscsoportokban fürtábrát készítenek, melyben összegyüjtik ötleteiket, szerintük mi lehet az alapcselekménye a Néró és a VII. A címü regénynek, 
milyen elvárásokat ébreszt bennük a mű címe. A kiscsoportos megbeszéléseket követően egy csomagolópapírra összegezzük az osztály elképzeléseit, majd félretesszük a házi olvasmányt feldolgozó órára. Néhány lehetséges ötlet:

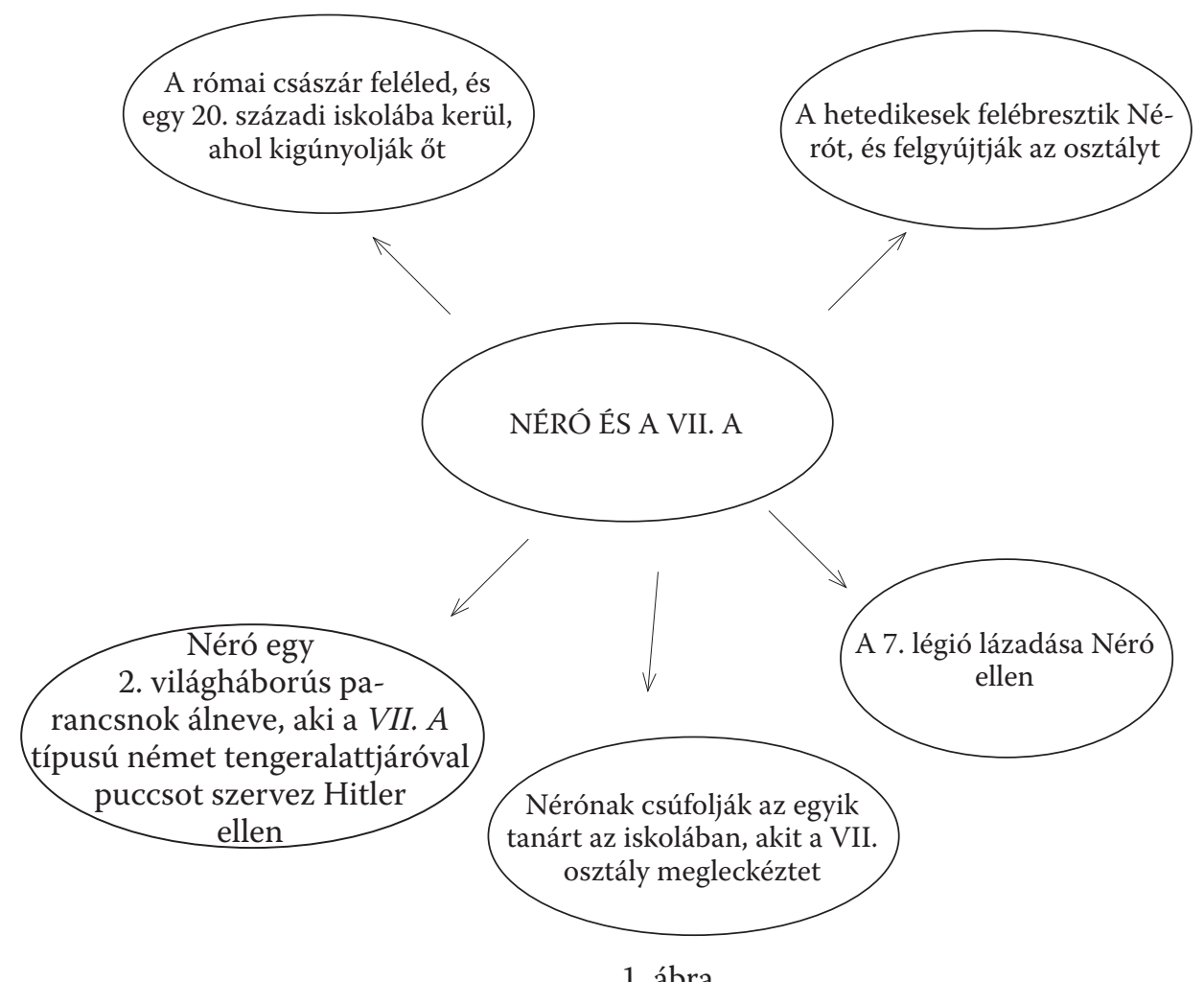

Jóslás fürtábra segítségével - néhány lehetséges ötlet

A szöveget feldolgozó tanórát a jóslatok frontális kiértékelésével kezdjük: megvitatjuk, vajon melyik jövendölés teljesült, születtek-e részben igaz jóslatok, mennyire felelt meg a mü az olvasói elvárásoknak, okozott-e (akár pozitív, akár negatív) csalódást az olvasmányélmény stb. A tapasztalatcserét végezhetjük kiscsoportban vagy frontálisan is.

2. Ki mit tud Perényiről? (csoportfeladat, grafikus ábrázolás, frontális megbeszélés): A szöveg a fegyelmi bizottság nyomozásával párhuzamosan mutatja be a föszereplöt. A cselekménysor felgöngyölítésével párhuzamosan fokozatosan nyerünk betekintést Perényi háromféle szerepkörébe, amiket a tanúként szólított kollégák - Knöpfler igazgató úr, Fürst Vera és Faragó 
Aurél - megítélései körvonalaznak, majd a mindentudó elbeszélő visszatekintő elbeszélései egészítenek ki. A gyakorlat a konfrontálódó nézőpontok és emlékezések szubjektivitására hívja fel a figyelmet, illetve rámutat, hogy az egyes szereplők mennyire beszűkült tudással - mégis milyen markáns, megingathatatlan véleménnyel - rendelkeznek Perényiről.

A diákokat kiscsoportba rendezzük, minden csoport húz egy szereplőnevet, majd a táblázatba feljegyzi, milyennek látja az adott szereplő a föhőst, milyen tulajdonságokat rendel hozzá, illetve hogyan ítéli meg identitásának átalakulását. Az egyes állításokat a szövegből vett indoklással támasztjuk alá. Példaként nézzük Fürst Vera véleményét:

1. táblázat

Szereplők tulajdonságai

\begin{tabular}{|c|c|c|c|c|c|}
\hline $\begin{array}{c}\text { Perényi } \\
\text { régebben }\end{array}$ & indoklás & $\begin{array}{l}\text { Perényi } \\
\text { idén }\end{array}$ & indoklás & $\begin{array}{c}\text { Perényi } \\
\text { most }\end{array}$ & Indoklás \\
\hline \multirow[t]{3}{*}{$\begin{array}{l}\text { Kitűnő } \\
\text { tanár: „Az } \\
\text { osztály } \\
\text { kedvence” }\end{array}$} & $\begin{array}{l}\text { Nem minden- } \\
\text { napi képzett- } \\
\text { ségű, kiváló az } \\
\text { előadókészsé- } \\
\text { ge, közvetlen a } \\
\text { diákokkal }\end{array}$ & \multirow{3}{*}{$\begin{array}{l}\text { Súlyosan } \\
\text { neuroti- } \\
\text { kus sze- } \\
\text { mélyiség, } \\
\text { a 40-es } \\
\text { férfiak } \\
\text { krízise } \\
\text { jellemzi: } \\
\text { "Patolo- } \\
\text { gikusan } \\
\text { szomjazza } \\
\text { a szerel- } \\
\text { müket" }\end{array}$} & $\begin{array}{l}\text { Megbukott, } \\
\text { elveszítette a } \\
\text { népszerűségét } \\
\text { - ok: Faragó } \\
\text { érkezése. Un- } \\
\text { ják a diákok, } \\
\text { közömbösek } \\
\text { iránta, nem } \\
\text { törődnek vele }\end{array}$ & \multirow[t]{3}{*}{$\begin{array}{l}\text { Zsarnok, } \\
\text { Nérónak } \\
\text { nevezik } \\
\text { el: „Már } \\
\text { nem az } \\
\text { osztályért } \\
\text { harcolt, } \\
\text { hanem az } \\
\text { osztály } \\
\text { ellen” }\end{array}$} & $\begin{array}{l}\text { Szerelme gyü- } \\
\text { löletbe csap át, } \\
\text { vérfagyasztó } \\
\text { terror }\end{array}$ \\
\hline & $\begin{array}{l}\text { Rajonganak } \\
\text { érte a diákok; } \\
\text { a folyosón, } \\
\text { udvaron körül- } \\
\text { állják, az utcán } \\
\text { kísérik }\end{array}$ & & $\begin{array}{l}\text { Harc a lányok } \\
\text { szerelméért: } \\
\text { monokli és } \\
\text { paróka viselése, } \\
\text { cikkével való } \\
\text { dicsekvés, elő- } \\
\text { adás tartása }\end{array}$ & & \multirow[t]{2}{*}{$\begin{array}{l}\text { A lányok } \\
\text { meggyűlölik, } \\
\text { állandóan sír- } \\
\text { nak, rettegnek } \\
\text { tőle }\end{array}$} \\
\hline & $\begin{array}{l}\text { Fiatal és mü- } \\
\text { velt }\end{array}$ & & $\begin{array}{l}\text { A lányok kigú- } \\
\text { nyolják: meg- } \\
\text { tapsolják, virá- } \\
\text { got adnak neki }\end{array}$ & & \\
\hline
\end{tabular}

A gyakorlat végén frontális megbeszélésre kerül sor, ahol összevetjük az egyes szereplők nézőpontjait, megállapítjuk Perényi korszakait (hódító, megalázkodó, zsarnok), majd az elbeszélő tudósításai alapján kiegészítjük a Perényiről kialakított olvasói képünket.

3. Kendözetlenül (csoportmunka, kreativ írás, frontális megbeszélés): Ebben a gyakorlatban a fegyelmi eljáráson kihallgatott tanúkon kívüli szereplőket juttatjuk szóhoz: Erdős Alizt, Gellén doktornőt, Décsy doktort, Décsy Magdát, Méreyt, Kocht és Klauseket. A diákok kiscsoportokra 
osztódnak, ezúttal azonban nem kívülről, hanem a szereplő karakterét magukra öltve szólalnak meg: minden csoport megírja az adott szereplő képzelt naplóbejegyzését, melyet a fegyelmi eljárás lezárásának éjszakáján vethetett volna papírra. A naplórészletek nemcsak a szereplők Perényiről alkotott valódi véleményét tartalmazzák, hanem az egész fegyelmi eljárást is értékelik, leleplezve az esetleges hátsó szándékokat, egyéni érdekeket is. Az elkészült szövegeket frontálisan bemutatjuk, az osztály hallgatósága pedig megpróbálja kitalálni, vajon kinek a képzelt naplójából származhat az idézet. A felolvasásokat frontális beszélgetés zárja, melyben a diákok megfogalmazzák, milyen jellemvonások, szófordulatok alapján ismerték fel a naplóírókat.

4. Vallatás (drámajáték, frontális megbeszélés): Perényi szövegszerủ és fiktív jellemábrázolásának vizsgálata után a föszereplőt juttatjuk szóhoz. A gyakorlat során a forró szék nevü drámajátékot alkalmazzuk, amely a vallatás eljárását mímelő helyzetgyakorlat: a csoport egy tagja az adott szereplő bőrébe bújva az osztállyal szemben foglal helyet, és a karakter nevében válaszolnia kell a hallgatóság kérdéseire. A játék érdekessége, hogy nem csupán a Perényit megtestesítő diákok alakítanak szerepet, hanem a faggató közönség is, mivel ők a VII. A nevében beszélnek. Perényit háromféle identitásában, három különböző diák segítségével szólaltatjuk meg: először mint hódítót vallatják a diákok (itt a „hetedikesek" a tanár rajongóiként kérdezősködnek), másodszor a zsarnok Perényit vallatja ki az osztály (a diákok megpróbálhatják felszínre hozni Perényi rejtett indítékait, szeretetéhségét), a harmadik szerepjáték pedig Perényi megtört identitását mozgósítja (az osztály kitérhet a fegyelmi eljárás következményeire).

5. Rajongások (csoportfeladat, grafikus ábrázolás, frontális megbeszélés): A szöveg egyik legmarkánsabb eleme a szerelem utáni vágy. Az elhallgatások, erotikus utalások ellenére azonban csupán nevetséges, szentimentális, egyoldalú szerelmek születnek; az egyetlen fizikailag is beteljesült szerelem pedig érzelmi síkon szenved hiányt. Ebben a feladatban a beteljesületlen szerelmeket térképezzük fel, és megvizsgáljuk azok bukásának okait, következményeit. A diákok csoportokba rendeződve dolgoznak - minden kiscsoport feldolgozza a regénybeli szerelmi viszonyok egyik típusát (testi, leszbikus, nárcisztikus, plátói szerelmek): megnevezik a rajongó(ka)t és az imádott személyt, összegyűjtik a hódítási eszközöket, majd megvizsgálják a rajongás hatását és következményeit. A kiscsoportos munkát követően frontálisan egy táblázatba gyüjtjük a feltérképezett kapcsolatokat, és kiemeljük a sejtetés, sugalmazás narrációs technikáinak eljárásait. 
2. táblázat

Rajongások formái a müben

\begin{tabular}{|l|l|l|l|l|}
\hline $\begin{array}{c}\text { A szerelmi } \\
\text { viszony típusa }\end{array}$ & $\begin{array}{c}\text { A rajongó és a } \\
\text { rajongás tárgya }\end{array}$ & $\begin{array}{c}\text { A rajongás } \\
\text { jegyei (hódítási } \\
\text { eszköz) }\end{array}$ & $\begin{array}{c}\text { Reakció a ra- } \\
\text { jongásra }\end{array}$ & $\begin{array}{c}\text { A rajongás } \\
\text { hatása, kö- } \\
\text { vetkezménye }\end{array}$ \\
\hline $\begin{array}{l}\text { Az öregedő férfi } \\
\text { fiatal lány(ok) } \\
\text { iránti rajongása } \\
\text { - plátói szere- } \\
\text { lem }\end{array}$ & & & & \\
\hline $\begin{array}{l}\text { Fiatal lány(ok) } \\
\text { idósebb férfi } \\
\text { iránti rajongása } \\
\text { - plátói szere- } \\
\text { lem }\end{array}$ & & & & \\
\hline Testi szerelem & & & & \\
\hline $\begin{array}{l}\text { Leszbikus sze- } \\
\text { relem }\end{array}$ & & & & \\
\hline $\begin{array}{l}\text { Nárcisztikus } \\
\text { szerelem }\end{array}$ & & & & \\
\hline
\end{tabular}

6. Bukott férfiak (páros munka, csoportmunka): A félrecsúszott szerelmeken kívül kisiklott életpályákkal, bukott férfiakkal is találkozunk a szövegben. A gyakorlat Klausek, Glas, Knöpfler és Faragó karakterét elemzi: a tanulók párban dolgoznak, ahol egy összehasonlító táblázatban összevetik az egyes szereplők jellemét, tetteit azzal, amilyenek lehettek volna. A szöveg valóságát tehát fiktív lehetőségekkel állítják szembe. A feladat azokra a fordulópontokra fókuszál, amikor az egyes karakterek vélhetőleg változtathattak volna a sorsukon, azonban elmulasztották ezt megtenni. Minden páros más szereplőt dolgoz fel, majd az egyforma karaktereket értelmező diákok kiscsoportokba tömörülve összevetik a meglátásaikat, végül egy-egy diák bemutatja az egész osztály előtt a véleménycsere eredményeit. 
A szereplő neve:

\begin{tabular}{|l|l|}
\hline A szereplő tettei & Mit kellett volna másképp tennie...? \\
\hline & \\
\hline & \\
\hline & \\
\hline
\end{tabular}

7. Osztálytalálkozó (drámajáték): Szituációs játékkal zárjuk a szövegfeldolgozást. A diákok szerepkártyákat húznak, és eljátsszák a 20 éves osztálytalálkozó képzelt osztályfőnöki óráját, ahová nemcsak az osztályfőnököt, hanem a fegyelmi eljárásban részt vett valamennyi résztvevőt meghívták. A feladat során elképzeljük, vajon hogyan alakult a szereplők további sorsa - és vajon hogyan emlékeznek vissza erre az incidensre két évtized távlatában a regény szereplői.

Komlós Aladár Néró és a VII. A című regényének elemzésvázlata és tanórai keretek közti feldolgozásának kísérlete a müben körvonalazódó személyes identitás és a nyilvánosságban felvállalt szerepek potenciális ellentmondásosságára és konfrontációjára, a tanár és diák közti kapcsolatrendszer bonyolultságára és csapdáira, a férfi és nő közti lehetséges kötelékek szövevényességére irányítja a figyelmet. Az 1935-ben megírt regény máig aktuális kérdéseket szegez az olvasójának, hiszen arra ösztönzi, hogy a felkínált szerepmodelleket a saját életére vetítse rá. A szöveg értelmezése a tanári pálya presztízsének a kérdését is felveti, és kiváló lehetőséget biztosít a tanári pályáról alkotott személyes víziók és társadalmi elvárások megvitatására, valamint a jól működő, hatékony tanár-diák kapcsolat feltételeinek a megfogalmazására.

\section{Irodalom}

Baranyai, N. (2003). Személyiségfejlődés, nevelődés, költői identitás. Hitel, 16(4), 53-69. Kaposi, L. (2002). Játékkönyv. Kapitális Kft..

Karinthy, F. (1936). Néró és a VII. A. Nyugat, 28(1). o.n.

Kiss, J. (2000). Bevezetés a gyermekirodalomba. Polis..

Komlós, A. (1958). Néró és a VII. A. Magvetö.

Kosztolányi, D. (1925). Aranysárkány. Légrády.

Móricz, Zs. (1920). Légy jó mindhalálig. Athenaeum.

Pethőné Nagy Cs. (2005). Módszertani kézikönyv. Korona.

Samu, Á. (2004). Kreatív írás. Holnap.

Szabó, M. (1970). Abigél. Móra.

Ujvári, L. (1936). Bukott tanárok. Korunk, 11(3), 266-269. https://doi.org/10.1093/ icesjms/11.2.266-a 


\section{Petres Csizmadia, G.}

\section{Stories of failed teachers}

This paper investigates the identity constructions in Aladár Komlós's novel Néró és a VII. A [Nero and VII/A] primarily by focusing on the character portrayal of some of the teachers, and then I attempt to apply the results of these interpretations in a classroom context. This school novel published in 1935 shows, on the one hand, how subtle is the teacher-student relationship, and on the other, it vividly depicts the malleable nature of the teacher characters' personal and professional identities. In the story, which also can be read as a novel describing the arc of a career, we follow the decline in the popularity of the main character, an irreversible process that defines the daily life of the teachers both as regards his colleagues and his students. In the methodological guidelines that follow the analysis I employ cooperative educational methods to offer an alternative way of incorporating the study of novel into contemporary classes in literature.

Keywords: school novel, identity construction, teacher identity, personal identity, methodology of literature 